\title{
Measurement of Fetal Penile Length in Thrace Region of Turkey
}

\author{
Türkiye'nin Trakya Bölgesi'nde Fetal Penis Uzunluk Ölçümü
}

\author{
Cem Yener, Fusun Varol, Esra Altan Erbilen, Sinan Ates, Cenk Sayin \\ Department of Obstetrics and Gynaecology, Division of Perinatology, Trakya University Faculty of Medicine, Edirne, Turkey
}

\begin{abstract}
Aim: To provide a reference range for fetal penile length obtained by prenatal sonography between 19th and 23rd weeks of pregnancy.

Material and Method: The medical records of pregnant women who were followed-up in our department of Perinatology during the time period of 1st of January 2019 to 31st of December 2019 were reviewed retrospectively. Total 103 patients between 19th and 23rd weeks of gestation were included in the study.

Results: Fetal penile length increased as the gestation proceeded. Mean $\pm S D$ penile length $(\mathrm{cm})$ between 19th and 23rd weeks of gestation was found to be $0.81 \pm 0.23$.

Conclusion: Ultrasound measurements of fetal penile length can be performed within the second-trimester anomaly scan, and these measurements appear to be necessary because identification of true penile maldevelopment obligates further diagnostic workup.
\end{abstract}

Key words: penis; prenatal diagnose; ultrasound

\section{ÖZET}

Amaç: On dokuz ile yirmi üçüncü hafta arasındaki fetüslerde fetal penis uzunluğu için referans aralığı hazırlamayı amaçladık.

Materyal ve Metot: Perinatoloji Kliniğimizde 1 Ocak 2019 ile 31 Aralık 2019 tarihleri arasında takip edilen gebelerin dosyaları retrospektif incelendi. Çalıșmaya 19 ile 23 gebelik hafta arasındaki 103 hasta alındı.

Bulgular: Fetal penis uzunluğu gebelik haftası ilerledikçe artmıș gözlendi. 19 ile 23 haftalar arası mean \pm SD fetal penis uzunluğu

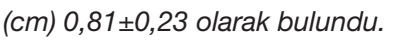

Sonuç: Ikinci trimester ultrason muayenesi sırasında fetal penis uzunluğu ölçülebilir. Penis gelișimindeki kusurların belirlenmesi daha ileri tanısal çalıșmayı zorunlu kıldığından bu ölçümler gerekli görülmektedir.

Anahtar kelimeler: penis; prenatal tanı; ultrason

\section{Introduction}

Determination of fetal sex with ultrasound is performed not only by family request, but also for defining normal gender development ${ }^{1}$. Determination accuracy of sex increases with gestation from $70 \%$ at 11 weeks, to $100 \%$ at 13 weeks ${ }^{2}$. Visualization of the fetal gender is necessary because early diagnosis of anomalies of the genitalia may help to provide expeditious diagnosis of different diseases, such as miscellaneous genetic syndromes and endocrinological disorders ${ }^{3}$.

In this retrospective study our objective was to set a reference chart for fetal penile length acquired by detailed sonography between the 19 th and 23 rd weeks of pregnancy.

\section{Material and Method}

The medical records of pregnant women who were followed-up in Trakya University School of Medicine, Department of Obstetrics\&Gynaecology, Division of Perinatology between $1^{\text {st }}$ of January 2019 to $31^{\text {st }}$ of December 2019 were reviewed retrospectively. Ethical approval was obtained from Trakya University Human Ethics Committee (No: 2020/275). We studied 25 patients in between 19 weeks (w) and 19 w 6 days (d), 27 patients between $20 \mathrm{w}$ and $20 \mathrm{w}+6 \mathrm{~d}, 26$ patients between $21 \mathrm{w}$ and $21 \mathrm{w}+6 \mathrm{~d}$ and 25 patients between $22 \mathrm{w}$ and $22 \mathrm{w}+6 \mathrm{~d}$. All pregnancies were singleton and accurately dated by first-trimester sonography. Fetuses were free of structural and chromosomal abnormalities. We excluded patients with abnormal first and second trimester screening tests or cell-free DNA test. We

Iletișim/Contact: Cem Yener, Trakya University Faculty of Medicine, Department of Obstetrics and Gynaecology, Division of Perinatology, Edirne, Turkey・Tel:05327486180 • E-mail:drcemyener@hotmail.com • Geliș/Received:25.08.2020 • Kabul/Accepted: 16.06.2021

ORCID: Cem Yener, 0000-0002-3976-4492 • Füsun Varol, 0000-0003-1918-4746 • Esra Altan Erbilen, 0000-0002-2859-1039 • Sinan Ateş, 0000-0001-9650-8340 • Cenk Saym, 0000-0001-5491-5431 

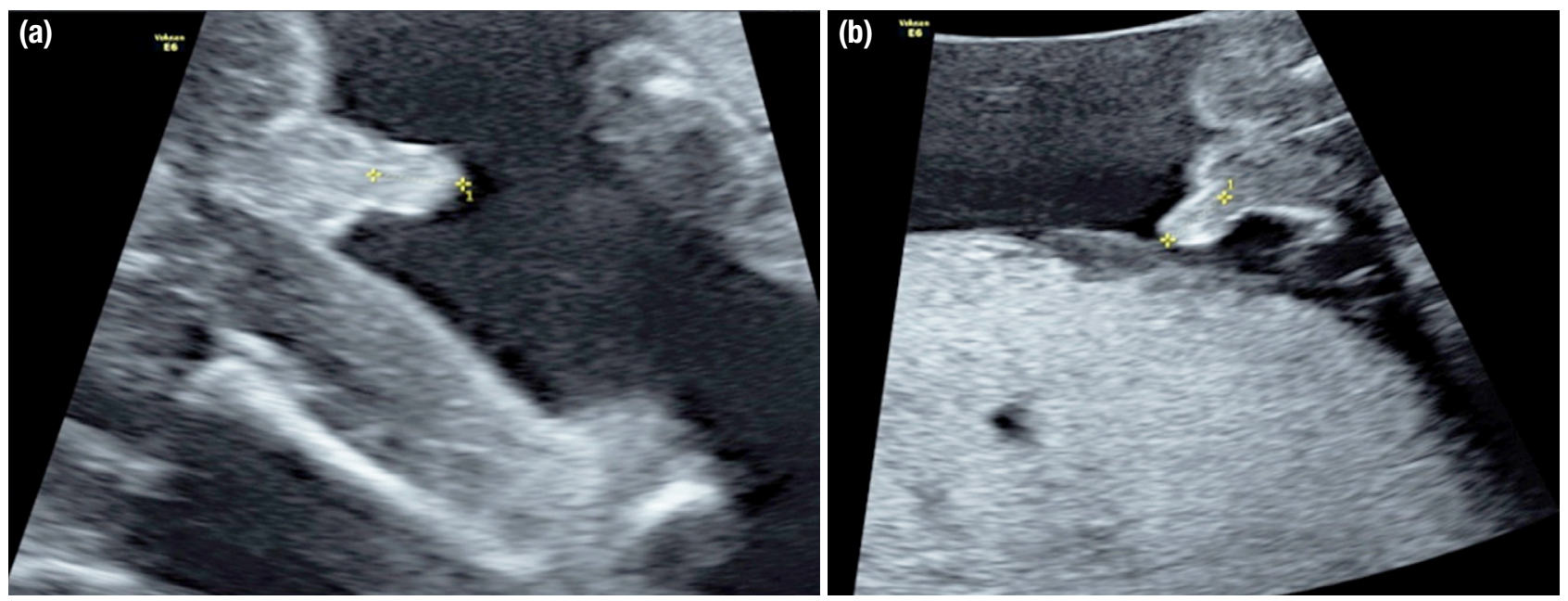

Figure 1. a, b. Measurement of penile length at 19 weeks (a) and 21 weeks (b) of gestation.

also excluded patients that developed abnormal signs on ultrasonography in late weeks of pregnancy or pregnancies complicated by fetal growth restriction, oligohydramnios and polyhydramnios.

For measuring the penile length, a clear view of the longitudinal axis of the scrotum and penis was obtained. The image was magnified and penile length was measured from the edge of the scrotum to the tip of the glans (Figure 1).

All measurements were acquired by 1 of 2 different obstetric sonographers (C. Y, E. A). In all cases, Voluson E6 ultrasound systems (GE Healthcare, Milwaukee, WI) with a $2 \mathrm{D}(4.5-16.5 \mathrm{MHz})$ transabdominal probe was used.

The statistical analysis was performed using SPSS Statics v25. Mean \pm standart deviation (SD) and percentile values of penile length were calculated for appropriate gestational weeks.

\section{Results}

The study group included 103 pregnancies at gestational ages between $19 \mathrm{w}$ and $22 \mathrm{w}+6 \mathrm{~d}$. Mean \pm SD and $5^{\text {th }}, 95^{\text {th }}$ percentile of penile length between 19 $\mathrm{w}$ and $19 \mathrm{w}+6 \mathrm{~d}(\mathrm{n}=25)$ were $0.76 \pm 0.22 \mathrm{~cm}, 0.3 \mathrm{~cm}$, and $1.12 \mathrm{~cm}$. Between $20 \mathrm{w}$ and $20 \mathrm{w}+6 \mathrm{~d}(\mathrm{n}=27)$ were $0.79 \pm 0.23 \mathrm{~cm}, 0.34 \mathrm{~cm}$ and $1.18 \mathrm{~cm}$. Between $21 \mathrm{w}$ and $21 \mathrm{w}+6 \mathrm{~d}(\mathrm{n}=26)$ were $0.83 \pm 0.24 \mathrm{~cm}, 0.4$ $\mathrm{cm}$ and $1.24 \mathrm{~cm}$. Between $22 \mathrm{w}$ and $22 \mathrm{w}+6 \mathrm{~d}(\mathrm{n}=25)$ were $0.88 \pm 0.23 \mathrm{~cm}, 0.47 \mathrm{~cm}$ and $1.28 \mathrm{~cm}$ respectively (Table 1), (Figure 2).

\section{Discussion}

Between $19^{\text {th }}$ and $23^{\text {rd }}$ weeks of the pregnancy, all systems of the fetus should be evaluated during sonographic screening. Since the abnormal appearance of genitalia is associated with various congenital and structural anomalies, fetal penile length assessment is a plausible parameter for target ultrasonography. In present study, the fetal penile length varied from 0.3 $\mathrm{cm}$ to $1.28 \mathrm{~cm}$ between 19th and 23rd weeks of the gestation. In literature there are studies from various geographies. For Israel population between 19th and 24th weeks of the gestation, penile length varied from $0.4 \mathrm{~cm}$ to $1.2 \mathrm{~cm}^{4}$. There is one study for Turkish population in literature which observed median fetal penile lengths between $0.79 \mathrm{~cm}$ and $0.85 \mathrm{~cm}$ in the same gestational weeks compatible with our results 5 . When we compared our measurements with previous

Table 1. Mean values and 5th and 95th percentiles of penile length by gestational week

\begin{tabular}{lccc}
\hline & & \multicolumn{2}{c}{ Percentiles } \\
\cline { 3 - 4 } Gestational week & Mean $(\mathrm{cm}) \pm S D$ & $\% 5$ & $\% 95$ \\
\hline $19 w-19 w+6 \mathrm{~d}(\mathrm{n}=25)$ & $0.76 \pm 0.22$ & 0.3 & 1.12 \\
$20 \mathrm{w}-20 \mathrm{w}+6 \mathrm{~d}(\mathrm{n}=27)$ & $0.79 \pm 0.23$ & 0.34 & 1.18 \\
$21 \mathrm{w}-21 \mathrm{w}+6 \mathrm{~d}(\mathrm{n}=26)$ & $0.83 \pm 0.24$ & 0.4 & 1.24 \\
$22 \mathrm{w}-22 \mathrm{w}+6 \mathrm{~d}(\mathrm{n}=25)$ & $0.88 \pm 0.23$ & 0.47 & 1.28 \\
\hline
\end{tabular}

w, weeks; d, days; SD, standart deviation n: number. 


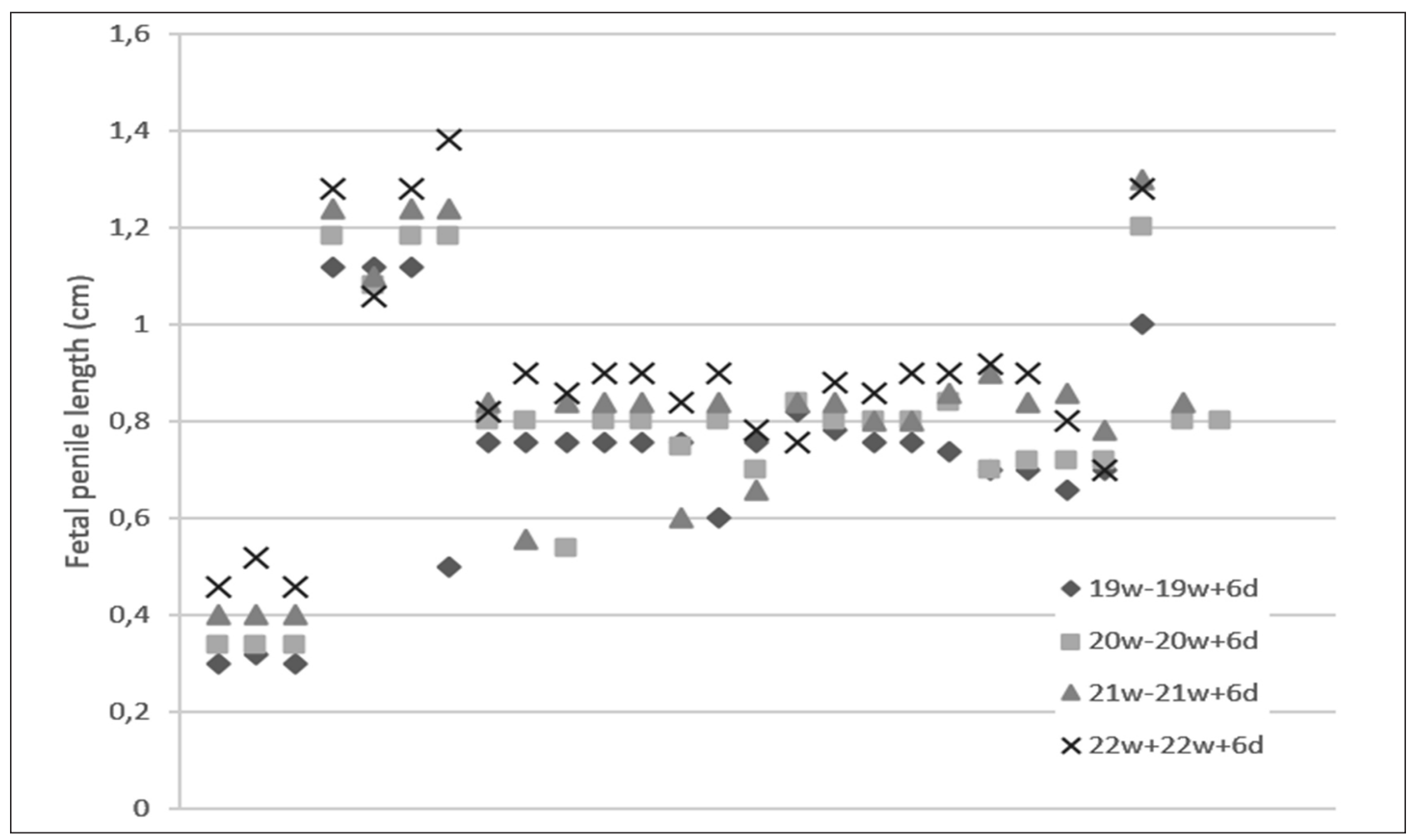

Figure 2. Fetal penile length measurements according to the gestational weeks (w, weeks; $d$, days).

reports of English ${ }^{6}$ and American ${ }^{7}$ populations, we observed that our reference ranges were similar to their reports. Based on these findings, we may conclude that our nomogram for penile measurements is applicable to Caucasian populations in utero.

Micropenis refers to small penis length less than 2.5 SD. It is observed in male fetus with ambiguous genitalia. When it is detected it can be associated with chromosomal abnormalities such as trisomy 13 and triploidy ${ }^{8}$. In addition, it can be related to genetic syndromes such as Smith-Lemli-Opitz, Noonan, PraderWilli and WAGR syndrome ${ }^{9-11}$. Male_hypogonadism is a condition in which the body does not produce enough of the testosterone hormone and it can cause micropenis. Primary hypogonadism is caused by various genetic syndromes such as Klinefelter, Prader-Willi and Bardet-Biedl ${ }^{12}$. When micropenis is identified, a diligent search for other defects is essential. In the presence of micropenis, genetic counselling should be considered as well as diagnostic testing. Amniocentesis with microarray testing should be contemplated for karyotype, particularly if there are other associated anomalies. When prenatal genital anomaly is detected, it is also necessary to deliver these fetuses in multidisciplinary hospitals to decrease morbidity because newborns should go through diagnostic tests. Neonate should be examined carefully to assess for other anomalies. Postnatal management of micropenis requires a multidisciplinary approach involving specialist in urology, endocrinology and genetics.

In differential diagnosis of bladder outflow obstructions, fetal penile length measurement is also useful. When the cause of bladder outflow obstruction is posterior urethral valves, penile length is usually normal. However, in case of urethral agenesis the penis may be very small. This differentiation can help the physician when informing the parents because while the former anomaly is associated with normal external genitalia appearance and function, the latter is related to poor outcome ${ }^{13}$.

In conclusion, we set normal ranges for the fetal penile length in the Thrace Region of the Turkey. The results of the study were consistent with the previous studies that evaluated fetal penile measurements. Identifying maldevelopment of the male genitalia is important because it helps early diagnosis of different diseases, 
such as genetic syndromes and endocrinological disorders. When micropenis is detected, careful ultrasound examination should be performed to search for coexisting structural anomalies. Diagnostic genetic tests should be considered for karyotype and molecular testing. Delivery in tertiary care facility is recommended. Neonate should be examined for additional malformations. Consultation with geneticist, endocrinologist and urologist is indispensable.

\section{References}

1. Achiron R, Pinhas-Hamiel O, Zalel Y, Rotstein Z, Lipitz $S$. Development of fetal male gender: prenatal sonographic measurement of the scrotum and evaluation of testicular descent. Ultrasound Obstet Gynecol 1998;11(4):242-245.

2. Efrat Z, Akinfenwa $\mathrm{O}$, Nicolaides $\mathrm{K}$. First-trimester determination of fetal gender by ultrasound. Ultrasound Obstet Gynecol 1999;13:305-307.

3. Indyk JA. Disorders/differences of sex development (DSDs) for primary care: the approach to the infant with ambiguous genitalia. Transl Pediatr 2017;6(4):323-334.

4. Zalel Y, Pinhas-Hamiel O, Lipitz S, Mashiach S, Achiron R. The development of the fetal penis - an in utero ultrasonographic evaluation. Ultrasound Obstet Gynecol 2001;17(2):129-131.
5. Akpinar F, Yilmaz S, Akdag Cirik D, Kayikcioglu F, Dilbaz B, Yucel H, et al. Sonographic Assessment of the Fetal Penile Development. Fetal Pediatr Pathol 2016;35(2):88-92.

6. Johnson P, Maxwell D. Fetal penile length. Ultrasound Obstet Gynecol 2000;15(4):308-310.

7. Pinette MG, Wax JR, Blackstone J, Cartin A. Normal growth and development of fetal external genitalia demonstrated by sonography. J Clin Ultrasound 2003;31(9):465-472.

8. Yatsenko SA, Witchel SF. Genetic approach to ambiguous genitalia and disorders of sex development: What clinicians need to know. Semin Perinatol 2017;41(4):232-243.

9. Yart A, Edouard T. Noonan syndrome: an update on growth and development. Curr Opin Endocrinol Diabetes Obes 2018;25(1):67-73.

10. Angulo MA, Butler MG, Cataletto ME. Prader-Willi syndrome: a review of clinical, genetic, and endocrine findings. J Endocrinol Invest 2015;38(12):1249-1263.

11. Fischbach BV, Trout KL, Lewis J, Luis CA, Sika M. WAGR syndrome: a clinical review of 54 cases. Pediatrics 2005; 116(4):984-988.

12. Hatipoğlu N, Kurtoğlu S. Micropenis: etiology, diagnosis and treatment approaches. J Clin Res Pediatr Endocrinol 2013;5(4):217-223.

13. Berrocal T, López-Pereira P, Arjonilla A, Gutiérrez J. Anomalies of the distal ureter, bladder, and urethra in children: embryologic, radiologic, and pathologic features. Radiographics 2002;22(5):1139-1164. 